\title{
ZARZĄDZANIE POMNIKAMI HISTORII
}

\section{MOLSKI Piotr $^{1}$}

${ }^{1}$ prof. nzw. dr hab. inż. arch. Piotr Molski, Wydział Architektury Politechniki Warszawskiej https://orcid.org/0000-0003-1541-6618

ABSTRAKT: System ochrony zabytków w Polsce, w tym pomników historii, nie jest w pełni dostosowany do zmian ustrojowych, które zaszły po 1989 roku. Niedocenianym, istotnym elementem tego systemu determinującym skuteczną ochronę jest profesjonalne zarządzanie architektonicznym dziedzictwem, łączące konserwację ze współczesnym użytkowaniem historycznych obiektów. Współzależności konserwatorskich i pozakonserwatorskich uwarunkowań wymuszają dziś postrzeganie ochrony zabytków jako złożonego i interdyscyplinarnego procesu - skorelowanych ze sobą oddziaływań na zabytkowy obiekt, w którym zabiegi konserwatorskie są kluczową, ale nie jedyną działalnością. Całością organizacyjną tych działań jest zarządzanie. Pomniki historii jako najcenniejsze dziedzictwo powinny być wzorem zarządzania dla krajowego, zabytkowego zasobu. Piętnastoletnie doświadczenia pomnika Twierdza Srebrna Góra pozwalają przybliżyć cele i złożone uwarunkowania powiązanych ze sobą działań zarządczych oraz wnioski adresowane do władz krajowych odpowiedzialnych za ochronę kulturowego dziedzictwa.

SŁOWA KLUCZE: Zarządzanie, pomniki historii, Srebrna Góra

\section{Wprowadzenie}

Teoria i praktyka ochrony i konserwacji zabytków dysponuje bogatym dorobkiem metodycznym i technologicznym. Funkcjonujący dziś w Polsce system ochrony zabytków sprawia, że w wielu przypadkach dorobek ten nie jest wykorzystywany.

W efekcie zmian ustrojowych po 1989 roku ochrona zabytków przestała być autonomiczną działalnością specjalistów-konserwatorów finansowaną przez państwo. Restytucja prawa własności, odpowiedzialność właścicieli zabytkowych obiektów za utrzymanie ich wartości, udział zabytków w rynkowym obrocie nieruchomościami, a przede wszystkim warunkujące ich ochronę współczesne użytkowanie sprawia, że o skuteczności działań gwarantujących zachowanie architektonicznego dziedzictwa decyduje już nie tylko specjalistyczna wiedza konserwatorska, ale też wiele czynników leżących poza obszarem konserwacji i restauracji zabytków - uwarunkowań prawnych, gospodarczych i społecznych. Ochrona zabytków wiąże się integralnie $\mathrm{z}$ ich użytkowaniem. Wymaga to modernizacji i adaptacji do współczesnych funkcji z dostosowaniem 


\section{Piotr Molski}

do aktualnych wymogów techniczno-użytkowych: norm cieplnych, wyposażenia w instalacje, systemy przeciwpożarowe, ewakuacyjne i inne. Poszerza to znacznie skalę uwarunkowań, a w tym zakres niezbędnych dokumentacji i uzgodnień branżowych. Determinantą zakresu i tempa prac konserwatorsko-adaptacyjnych są środki finansowe właściciela zabytku oraz możliwość pozyskiwania dotacji z budżetów państwa, samorządów i programów unijnych.

Współzależności konserwatorskich i pozakonserwatorskich uwarunkowań wymuszają dziś postrzeganie ochrony zabytków jako złożonego i interdyscyplinarnego procesu - skorelowanych ze sobą oddziaływań na zabytkowy obiekt, w którym zabiegi konserwatorskie są kluczową, ale nie jedyną działalnością.

Jeśli zamierzonym celem tych oddziaływań jest zachowanie zabytku, powiązane z jego zagospodarowaniem i często komercyjnym użytkowaniem, to całość organizacyjną tych oddziaływań można określić mianem zarządzania obiektem zabytkowym ${ }^{1}$. Działania te obejmują: planowanie (wybór celów i sposobów ich osiągania oraz precyzowanie stosownych zadań i terminów ich wykonania); organizowanie (przydzielanie i zapewnianie zasobów, niezbędnych do realizacji zaplanowanych działań w sposób gwarantujący skuteczność i sprawność zarządzania); przewodzenie (kierowanie, motywowanie do współpracy w trakcie realizacji zadań); kontrolowanie (stała obserwacja postępów i podejmowanie korygujących decyzji) ${ }^{2}$.

Różnorodne, wymagające korelacji obszary aktywności (opieka nad zabytkiem, inwestycje konserwatorsko-adaptacyjne i gospodarcze oraz dydaktyczne i komercyjne funkcje) wymagają udziału wykwalifikowanej kadry.

Jeszcze kilka lat temu dyskusje w środowiskach zajmujących się zabytkami koncentrowały się głównie wokół metod konserwacji obiektów. Praktycznym aspektom zarządzania zabytkowym zasobem poświęcano dużo mniej uwagi. Dzisiaj skuteczność ochrony uzależniona jest od jakości zarządzania, a pomniki historii jako najcenniejsze i reprezentatywne dla krajowego zasobu zabytków powinny stanowić w tym zakresie wzorce.

Cechy pomników historii w Polsce są zróżnicowane. Ponad 40\% z nich to założenia sakralne i klasztorne; $17 \%$ - zespoły miejskie; $10 \%$ stanowią obiekty poprzemysłowe; $8 \%$ - zespoły pałacowo-parkowe, zamkowo-parkowe i dworsko pałacowe; $4 \%$ to zamki, tyleż samo twierdze nowożytne i zespoły krajobrazowe. Pozostałe to pojedyncze obiekty o różnych, historycznych funkcjach i formach ${ }^{3}$. Zdecydowana większość z nich to zespoły o dużej skali przestrzennej. Różnią się od siebie położeniem, warunkami klimatycznymi, fizjograficznymi, strukturą budowlano-materiałową i przestrzenną, dostępnością komunikacyjną, możliwościami pozyskiwania środków finansowych, formułą zarządzania czy proweniencją.

1 Zarządzanie jest wyodrębniającą się specjalnością, której poświęcone są liczne badania i publikacje odnoszące się do różnych dziedzin życia społeczno-gospodarczego; w niniejszych rozważaniach przyjęto ogólną definicję: zarządzanie - działania skierowane na całości organizacyjne, które polegają na osiągnięciu zamierzonych celów - według: Słownika Języka Polskiego, https://sjp.pl dostęp:10.07.2019 r.

2 Encyklopedia PWN - https://encyklopedia.pwn.pl/haslo/zarzadzanie;4000464.html; dostęp 10.07.2019

$3 \mathrm{Na}$ podstawie danych Narodowego Instytutu Dziedzictwa: https://www.nid.pl/pl/Informacje_ogolne/ Zabytki_w_Polsce/Pomniki_historii/; dostęp 2.08.2019 r. 
Próba przybliżenia, w dalszych rozważaniach, najbardziej istotnych uwarunkowań i czynników decydujących o skuteczności ochrony obiektu oparta jest na piętnastoletnich doświadczeniach Pomnika Historii „Twierdzy Srebrnogórskiej, nowożytnej warowni górskiej z XVIII wieku” należącej do typologicznej grupy zabytków obronnych okresu nowożytnego (Ryc.1). Warownia srebrnogórska wpisana została na Listę Pomników Historii w 2004 roku.

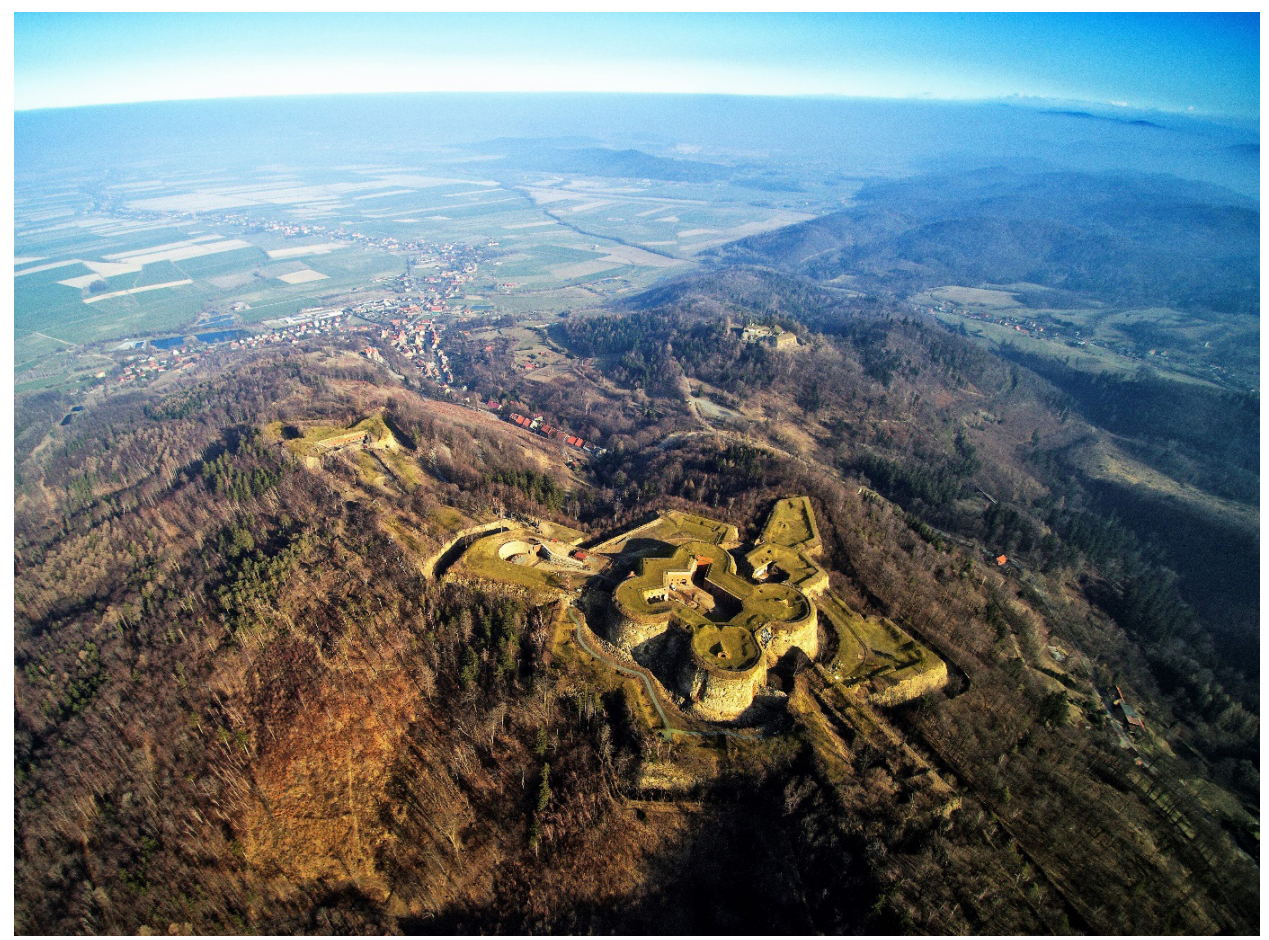

Fot. 1 Twierdza Srebrna Góra, fot. G. Basiński

\section{Zarządzanie Twierdzą Srebrnogórską}

Monumentalny zespół górskiej twierdzy skupia w sobie unikatowe wartości, a jednocześnie szczególnie złożone uwarunkowania ich ochrony. Warownia Srebrnogórska, to zespół budowli murowych i ziemnych ułożonych w paśmie umocnień o długości ok. $3,0 \mathrm{~km}$, położony na wysokości 680 - $750 \mathrm{~m}$ n.p.m., na zróżnicowanym wysokościowo terenie o powierzchni 106 ha. Struktura przestrzenna i budowlana twierdzy z założenia powiązana $\mathrm{z}$ naturalnymi, górskimi przeszkodami terenowymi miała w możliwie największym stopniu ograniczać dostęp wrogich wojsk. Historycznie było to ogromną zaletą, ale dziś stanowi jeden $\mathrm{z}$ istotnych problemów związanych z dostępnością komunikacyjną obiektu. Wizyta w twierdzy wymaga pieszej, 25 minutowej wędrówki stromym, ponad kilometrowym podejściem z leżącego u podnóża parkingu. Uniemożliwia to zwiedzanie obiektu osobom starszym i niepełnosprawnym.

Do lat 90. XX w. twierdza pozostawała w stanie ruiny podlegającej coraz szybszej destrukcji potęgowanej ostrym, górskim mikroklimatem. Prowadzone systematycznie od początków lat 
dwutysięcznych prace konserwatorskie pozwoliły opanować procesy deterioracji w głównej części warowni - zespole donżonu. Cele i priorytety koncentrują się wokół likwidacji stanów awaryjnych i katastrof budowlanych, remontów zabezpieczających budowle przed oddziaływaniem warunków klimatycznych - szczególnie wilgoci (z restytucją historycznych systemów odwadniających i wentylacyjnych) oraz na eliminacji zieleni inwazyjnej. Codziennym niemal problemem jest organizacja prac remontowych wymagająca pokonania barier związanych z ukształtowaniem terenu i wysokością budowli. Jako przykład służyć może remont warstwy licowej wież donżonu o wysokości około $30 \mathrm{~m}$. dostępnych jedynie z fosy o głębokości sięgającej 9 m. (Ryc. 2)

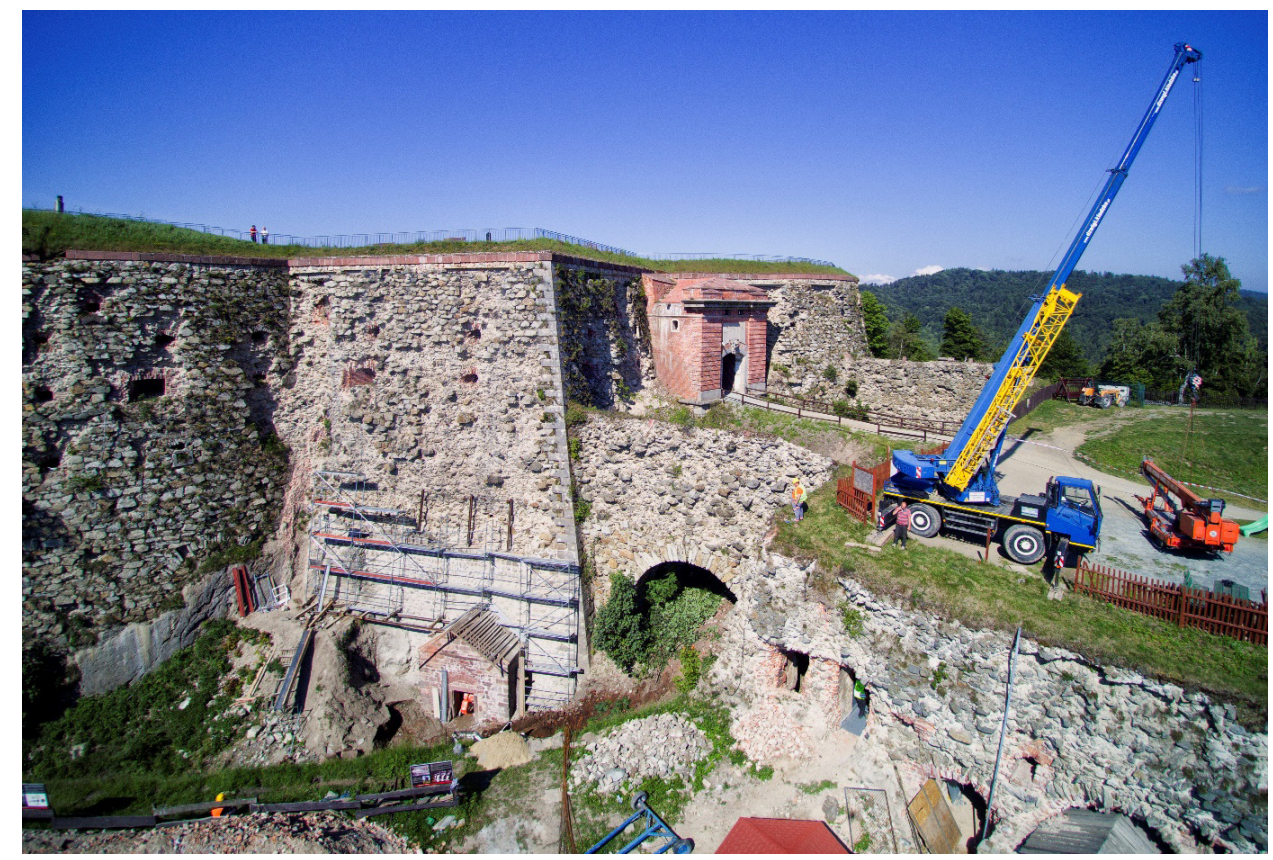

Fot. 2 Remont wieży donżonu Twierdzy Srebrna Góra, fot. G. Basiński

Pilnego rozwiązania wymaga umożliwienie dostępu ekipom remontowym do ulegających postępującej destrukcji Fortu Rogowego i esplanady łączącej ten fort z donżonem twierdzy, powiązanych niegdyś mostami w fosach. $Z$ tego względu znaczna część twierdzy jest wyłączona z prac konserwatorskich. Ich rozpoczęcie umożliwi odtworzenie sześciu mostów. Sporządzono w tym celu niezbędną dokumentację budowlaną, ale projekt nie uzyskał wsparcia finansowego z programu operacyjnego Infrastruktura i Środowisko. Odrębnym problemem jest zabezpieczenie i udostępnienie turystyczne trwałej ruiny zespołu umocnień Chochołów stanowiących integralną część twierdzy, leżących na terenie Lasów Państwowych.

Cele związane z użytkowaniem obiektu to:

- nadanie-odpowiedniej dla unikatowego pomnika historii-rangi dydaktycznejpoprzez rozwój funkcji ekspozycyjnych i kulturalno-rekreacyjnych (w twierdzy stale udostępniane są turystom kolejne wnętrza z ekspozycjami oraz wydłużane trasy zwiedzania); 
- wyposażenie zespołu w urządzenia i sieci infrastruktury technicznej oraz w usługi dla turystów i użytkowników spełniające współczesne standardy (zapewnienie niezbędnych parametrów zaopatrzenia w wodę i energię oraz odprowadzenia ścieków do sieci miejskich przy różnicach wysokości i górskiej rzeźbie terenu wymaga specjalnych rozwiązań4; przygotowana jest dokumentacja projektowa bazy noclegowej i gastronomicznej na donżonie twierdzy);

- zapewnienie bezpieczeństwa turystom i użytkownikom (co w górskiej twierdzy wymaga nieporównywalnie większych, niż w innych obiektach zabytkowych, nakładów pracy i środków);

- umożliwienie publicznego dojazdu do zabytkowego zespołu (opracowana jest dokumentacja projektowa kolejki gondolowej łączącej miasteczko Srebrna Góra z twierdzą).

Realizacja tych zadań jest warunkiem zwiększenia liczby odwiedzających turystów, co znacząco powiększy oddziaływanie edukacyjno-promocyjne pomnika historii, ale też dochody własne reinwestowane w utrzymanie obiektu.

Stałe prowadzenie i zintegrowanie różnych obszarów działań $\mathrm{w}$ monumentalnym zespole zabytkowym wymaga odrębnej jednostki zarządzającej. Jej umocowana prawnie formuła powinna być dostosowana do lokalnych uwarunkowań wynikających ze specyfiki obiektu, potencjału finansowego właściciela i możliwości wykorzystania różnych środków zewnętrznych. Dla Twierdzy Srebrna Góra rozważane były różne warianty: komórki zarządzającej w strukturach urzędu gminy (w praktyce, przy licznych zadaniach własnych gminy, wariant ten nie zdaje egzaminu), samorządowej instytucji kultury, fundacji, jednostki zarządzającej parkiem kulturowym (twierdza położona jest w granicach pierwszego w Polsce parku kulturowego) oraz spółki gospodarczej.

Twierdza leży na terenie rolniczej Gminy Stoszowice o rocznym budżecie wynoszącym ok. 25 mln. zł. Przy takim budżecie gmina ma daleko ograniczone moźliwości finansowania inwestycji i wkładów własnych do programów dotowanych ze źródeł zewnętrznych. Kondycja finansowa samorządu i utrudniona dostępność obiektu stanowiąca barierę w zwiększaniu ruchu turystycznego, a tym samym dochodów własnych, zadecydowały o wyborze gminnej spółki z o.o. jako optymalnej formuły jednostki zarządzającej.

Spółka generuje dochody z obsługi ruchu turystycznego i reinwestuje je w całości w utrzymanie i rozwój obiektu. Uzyskiwane dochody nie pozwalają na zatrudnienie, odpowiadających potrzebom, wykwalifikowanych pracowników. Obiektem zarządza jedynie dwuosobowy zespół merytoryczny z pomocą pracowników technicznych i siedmiu przewodników turystycznych (łącznie, w sezonie letnim - 11 osób) $)^{5}$.

Zadania etapowe $\mathrm{w}$ zakresie remontów konserwatorskich i zagospodarowania twierdzy są zdefiniowane, ale ich zakres i terminy realizacji nie są określone, co wiąże się z trudnym

\footnotetext{
4 Między innymi: przyłącze wodociągowe o długości 1300 m, energetyczne - 1400 m ze stacją transformatorową.

5 W gdańskim zespole pofortecznym „Hevelianum”, który nie ma statusu pomnika historii i zarządzany jest przez gminną instytucję kultury zatrudnionych jest 38 osób - trudno jednak porównywać bogaty Gdańsk z małą gminą rolniczą.
} 
do przewidzenia pozyskaniem środków zewnętrznych i brakiem czytelnych reguł polityki konserwatorskiej wobec pomników historii. Opóźnienia w zabezpieczeniu budowli przed postępującą destrukcją w oczywisty sposób wpływają na stale zwiększający się zakres interwencji konserwatorskich i likwidacji stanów awaryjnych.

Krótkie terminy realizacji prac remontowych (od przyznania dotacji do jej rozliczenia), przeciągające się $\mathrm{w}$ czasie procedury zamówień publicznych i coraz trudniejsze pozyskanie wyspecjalizowanych $\mathrm{w}$ remontach konserwatorskich firm, skrócony $\mathrm{w}$ warunkach górskiego klimatu sezon budowlany powodują poważne komplikacje w wykorzystaniu dotacji.

Organem opiniodawczo-doradczym przy Wójcie Gminy jest społeczna rada naukowokonserwatorska złożona ze specjalistów - członków Komisji Architektury Militarnej Polskiego Komitetu Narodowego ICOMOS. Do zakresu działania rady należy opiniowanie strategii, planów i działań, a w tym m.in.:

- dokumentacjiremontowych, konserwatorskich, budowlanych, programów funkcjonalnoużytkowych, wniosków aplikacyjnych o zewnętrzne dotacje;

- projektów, programów i zadań z zakresu popularyzacji i edukacji dotyczących ochrony dziedzictwa kulturowego;

- zmian władania nieruchomościami gminnymi na terenie parku i zmian sposobu ich użytkowania.

Współpraca zarządu twierdzy ze służbami konserwatorskimi układa się bardzo dobrze.

Reasumując - Zarząd Pomnika Historii Srebrna Góra realizuje powiązane ze sobą, następujące zadania ciągłe:

- gromadzenie dokumentacji historycznej - ikonograficznej, inwentaryzacyjnej, projektowej itp. (kwerendy w archiwach polskich i zagranicznych);

- monitorowanie stanu technicznego budowli;

- konserwacja profilaktyczna (konserwacja zabytkowej tkanki, infrastruktury technicznej, wyposażenia, małej architektury służącej bezpieczeństwu turystów itp.);

- programowanie zadań konserwatorsko-remontowych i modernizacyjno-adaptacyjnych;

- pozyskiwanie środków finansowych z działalności własnej (obsługa ruchu turystycznego, organizowanie imprez kulturalno-rekreacyjnych) oraz ze źródeł zewnętrznych (programy unijne, udział w konkursach na dofinansowania prac przy zabytkach); sporządzanie i finansowanie z własnych środków dokumentacji aplikacyjnych o dotacje zewnętrzne (bez gwarancji ich uzyskania);

- sporządzanie dokumentacji niezbędnej dla robót konserwatorskich, modernizacyjnych $i$ adaptacyjnych (inwentaryzacji przed i powykonawczych, dokumentacji ofertowo-przetargowej - zamówienia publiczne, dokumentacji projektowej - od koncepcji po projekty wykonawcze);

- programowanie i sporządzanie dokumentacji projektowej zadań inwestycyjnych związanych ze zwiększeniem zewnętrznej dostępności twierdzy (budowa kolejki gondolowej łączącej miasteczko Srebrna Góra z twierdzą oraz urządzeń i sieci infrastruktury technicznej; modernizacja dróg do 
twierdzy);

- realizacja i obsługa zadań inwestycyjnych (uzgodnienia konserwatorskie i branżowe, procedury ofertowe, zamówienia publiczne; zapewnienie nadzoru konserwatorskiego; obsługa finansowa itp.);

- organizacja i obsługa ruchu turystycznego, stałe zwiększanie atrakcyjności programów edukacyjnych, form eksponowania wartości zabytkowych i usług turystycznych;

- organizacja wydarzeń kulturalnych i imprez rekreacyjnych adresowanych do turystów;

- działalność naukowo-edukacyjna i popularyzatorska (upowszechnianie wartości zabytkowych, krajobrazowych i użytkowych obiektu, promocja pomnika historii w kraju i za granicą, informacja turystyczna i wydawnicza);

- zapewnianie bezpieczeństwa użytkownikom obiektu;

- współdziałanie z interesariuszami (służbą konserwatorską, władzami gminy i podmiotami gospodarczymi, organizacjami pozarządowymi);

- działalność na rzecz lokalnych społeczności i ich utożsamiania się z obiektem (organizacja wydarzeń kulturalno-rekreacyjnych dla społeczności lokalnych;

- współpraca z ośrodkami naukowymi i uczelniam, organizacja i udział w ogólnopolskich konferencjach naukowych;

- zapewnienie wykwalifikowanej kadry zarządzającej, technicznej i obsługi ruchu turystycznego (szkolenie kadr i przewodników).

\section{Wnioski}

Sposób zarządzania zasobami dziedzictwa architektonicznego determinowany jest systemem ustrojowo-prawnym, przygotowaniem kadr zarządzających i ich kreatywnością, uwarunkowaniami lokalnymi oraz dostępnymi środkami finansowymi.

Efektywne zarządzanie pomnikiem historii jest obecnie znacznie utrudnione. Przy większych inwestycjach remontowo-konserwatorskich brak jest pewności uzyskania dotacji zewnętrznych w następnych latach budżetowych, a w efekcie - nie ma możliwości strategicznego planowania, kontynuacji i płynnej realizacji zadań.

Opracowanie planów zarządzania, zabezpieczenie obiektów, utrzymanie w dobrym stanie i zapewnienie funkcji edukacyjnych wymaga, w zależności od stanu i specyfiki obiektu, wieloetapowych programów wspomagania merytorycznego i finansowego.

Z doświadczeń srebrnogórskich wynika (szczególnie w zespołach o dużej skali przestrzennej) potrzeba kompleksowego planu integrującego działania ochronne i zagospodarowanie obiektu. Złożoność problemów związanych z inwestycjami konserwatorsko-remontowymi, modernizacją iadaptacją zabytkowych struktur, ale też z uwarunkowaniami i wymogami pozakonserwatorskimi przesądza o tym, że plan taki, uwzględniający specyficzne cechy zabytkowej struktury jest 
niezbędny ${ }^{6}$.

Potwierdzają to zalecenia Konwencji Światowego Dziedzictwa i Wytycznych Roboczych UNESCO obligujące do opracowania planu zarządzania dla dobra wpisywanego na Listę Światowego Dziedzictwa. Zawartości modelowej tego dokumentu poświęcił wiele uwagi w publikacjach prof. Bogusław Szmygin. Czytamy w nich m.in.: „plan zarządzania przedstawia całościowa wizję założeń, priorytetów, celów, metod i instrumentów stużacych ochronie i zarzadzaniu danym dobrem; powinien mieć charakter kompleksowy i uwzględniać wszystkie zasadnicze czynniki, które oddziaływuja na dobro oraz obejmować wszelkie działania, które zarzadca dobra powinien podejmować, aby zapewnić mu odpowiednia ochronę i zarządzanie. Plan zarządzania $z$ zasady jest sporzadzany dla konkretnego dobra (zespołu dóbr). Musi zatem mieć charakter indywidualny i obejmować dane stanowiące o specyfice dobra, m.in. charakterystykę jego cech i wartości oraz czynników oddzialywujacych na to dobro."

Plany zarządzania powinny być uzupełniane przez plany zadaniowe - dokumenty robocze przedstawiające konkretne, okresowe zadania realizujące priorytety i cele określone w planie zarządzania. Mogą one dotyczyć problemów technicznych, finansowych, edukacyjnych, popularyzatorskich, turystycznych czy kulturalno-rekreacyjnych. Zapisy w tych dokumentach gwarantować powinny zachowanie historycznej integralności zabytkowego zespołu.

Plan zarządzania wyposażony w zadaniowe plany działania może stanowić istotny element systemowej ochrony pomnika historii jako:

- jeden z warunków nadania i posiadania statusu pomnika historii;

- podstawa decyzji o finansowaniu pomnika historii ze środków Ministerstwa Kultury i Dziedzictwa Narodowego i programów zewnętrznych oraz o przyznaniu kilkuletniej promesy dotacji - jeśli plany zadaniowe uzasadniają taką potrzebę. O wysokości i etapowaniu dotacji decydować powinny zawarte w planie informacje o skali, rodzaju i złożoności niezbędnych działań oraz niezwiązanych bezpośrednio z konserwacją uwarunkowaniach i barierach, których pokonanie wymaga również nakładów finansowych;

Treści planów i ich realizacja powinny być opiniowane i monitorowane przez Wojewódzkie Urzędy Ochrony Zabytków.

6 W końcu lat 90.XX. w. ówczesny Generalny Konserwator Zabytków zainicjował ogólnopolskie, finansowane ze środków Ministerstwa Kultury i Sztuki programy ochrony i konserwacji wybranych kategorii zabytków. Programy te realizowane były przez konserwatorów i przedstawicieli ośrodków naukowych z całego kraju, specjalizujących się w ochronie danej grupy zabytków. Jednym z głównych celów programów było opracowanie metod (standardów) ochrony wyodrębniających się swoją specyfiką zabytków. Np. istotną propozycją programu „Ochrona i konserwacja architektury obronnej” była potrzeba sporządzania - dla całego zespołu zabytkowego - spójnego programu ochrony i zagospodarowania zachowującego integralność zespołu, ujmującego strategię działań konserwatorsko-remontowych i powiązane z konserwacją etapy zagospodarowania, w oparciu o oceny stanu technicznego, wartości zabytkowych i możliwości adaptacyjno-modernizacyjnych (dziś wracamy do opracowania standardów nie uwzględniając często bogatego dorobku lat minionych).

Szmygin B.; Światowe dziedzictwo kultury UNESCO - charakterystyka, metodologia, zarządzanie; 2018, Warszawa -Lublin; PKN ICOMOS, Politechnika Lubelska; ss. 211 - 212. 
Specyfika cech poszczególnych pomników historii i uwarunkowań ochrony sprawia, że trudno byłoby ustalić standardowy model zarządzania pomnikami. Można jednak określić wiodące obszary zadaniowe:

- planowanie i programowanie strategiczne;

- gromadzenie i sporządzanie niezbędnych dokumentacji;

- pozyskiwanie środków finansowych;

- bieżące utrzymanie stanu technicznego obiektu;

- realizacja i obsługa zadań inwestycyjnych;

- obsługa programu użytkowego;

- działalność naukowa, edukacyjna i popularyzatorska;

- działalność na rzecz lokalnych społeczności;

- współpraca z samorządami, organizacjami pozarządowymi, podmiotami prowadzącymi działalność związaną z ochroną dziedzictwa i turystyką kulturową ze służbami konserwatorskimi $\mathrm{i}$ instytucjami naukowymi.

Zintegrowany zapis obszarów zadaniowych przedstawia tabela 1.

\begin{tabular}{|c|c|c|c|}
\hline OCHRONA WARTOŚCI ZABYTK. & EDUKACJA & \multirow{2}{*}{$\begin{array}{l}\text { UŻYTKOWANIE: turystyka, } \\
\text { kultura, rekreacja }\end{array}$} & \multirow{2}{*}{$\begin{array}{l}\text { INFORMACJA, } \\
\text { PROMOCJA } \\
\text { UPOWSZECHNIANIE }\end{array}$} \\
\hline \multicolumn{2}{|c|}{$\begin{array}{l}\text { GROMADZENIE DOKUMENTACII, KWERENDY (inwentaryzacje, archiwalia; } \\
\text { uwarunkowania i czynniki lokalne i ponadlokalne; prawne, planistyczne itp.) }\end{array}$} & & \\
\hline \multicolumn{4}{|c|}{ STRATEGICZNE PROGRAMOWANIE ZADAŃ - etapowanie } \\
\hline $\begin{array}{l}\text { Badania, konserwacja, restauracja, } \\
\text { adaptacja, modernizacja; dostępność do } \\
\text { obiektów }\end{array}$ & $\begin{array}{l}\text { Realizacja programów edukacyjnych; } \\
\text { formy ekspozycji wartości }\end{array}$ & $\begin{array}{l}\text { usługi towarzyszace; wyposażenie w } \\
\text { urządzenia i sieci infrastruktury } \\
\text { technicznej; system informacji }\end{array}$ & \multirow{8}{*}{$\begin{array}{l}\text { Publikacje } \\
\text { Informacje medialne } \\
\text { Konferencje, warsztaty } \\
\text { Zielone szkoły }\end{array}$} \\
\hline \multicolumn{3}{|c|}{ POZYSKIWANIE ŚRODKÓW FINANSOWYCH własnych i zewnętrznych; opracowanie dokumentacji aplikacyjnych } & \\
\hline \multicolumn{3}{|c|}{$\begin{array}{l}\text { SPORZADZANIE DOKUMENTACJI PROJEKTOWEJ konserwatorskiej, architektonicznej, branżowej, } \\
\text { REALIZACJA PROCESU INWESTYCYJNEGO - zarządzanie projektami (uzgodnienia, procedury zamówień publicznych, nadzory itp.) }\end{array}$} & \\
\hline \multicolumn{3}{|c|}{ UTRZYMANIE, EKSPLOATACJA I MONITORING OBIEKTU } & \\
\hline Bieżąca konserwacja profilaktyczna & \multirow{3}{*}{$\begin{array}{l}\text { szkolenie kadry i obsługi ruchu } \\
\text { turystycznego }\end{array}$} & $\begin{array}{l}\text { Obsługa ruchu turystycznego i organizacja } \\
\text { wydarzeń }\end{array}$ & \\
\hline \multirow[t]{2}{*}{ Monitoring stanu technicznego obiektu } & & $\begin{array}{l}\text { Konserwacja urządzeń infrastruktury } \\
\text { technicznej }\end{array}$ & \\
\hline & & $\begin{array}{l}\text { Zapewnienie dostępności i bezpieczeństwa } \\
\text { užytkownikom }\end{array}$ & \\
\hline & WSPÓtDZIALANIE Z INTE & ARIUSZAMI & \\
\hline
\end{tabular}

Tab. 1 Cele i rodzaje zadań w zintegrowanym procesie zarządzania

Jednostką zarządzającą pomnikiem historii powinien być wyodrębniony podmiot prowadzący działalność gospodarczą i dysponujący własnym budżetem (w przypadku obiektów pozasakralnych - spółka gospodarcza, spółka gospodarcza non-profit, gminna instytucja kultury). Rozwiązania, w których zabytkowy zespół jest jednym z kilku organizmów (całości organizacyjnych powołanych do zupełnie różnych celów) zarządzanych przez jedną jednostkę organizacyjną z reguły nie przynoszą właściwych efektów. Strategiczne decyzje w zakresie ochrony zabytków nie są podejmowane przez specjalistów w tej dziedzinie. Środki finansowe

8 Obszary zadaniowe sformułowane na podstawie wieloletniej współpracy autora z samorządami lokalnymi, gospodarzami i zarządcami zespołów zabytkowych. 


\section{Piotr Molski}

generowane przez turystykę i edukację kulturową zasilają zadania nie związane z ochroną obiektów9.

Umiejętność zarządzania zabytkowym zasobem jest, obok wiedzy konserwatorskiej, warunkiem niezbędnym skutecznej ochrony pomników historii. Problematyka zarządzania powinna być przedmiotem merytorycznej wymiany doświadczeń oraz współpracy zarządców pomników ze służbami konserwatorskimi, Narodowym Instytutem Dziedzictwa i ośrodkami naukowymi w Polsce. Zgodnie z polskimi regulacjami ustawowymi opieka nad zabytkami jest domeną ich właścicieli. Ochrona, rozumiana jako zapewnienie warunków dla zachowania dziedzictwa, leży w kompetencjach krajowych, regionalnych i lokalnych organów władz państwowych i samorządowych. Pomocą merytoryczną i finansową państwa dla pomników historii, jako najcenniejszej i wzorcowej pod względem opieki i zarządzania grupy zabytków, należy objąć wyodrębnionym, rządowym programem ochrony dziedzictwa.

Taki złożony model funkcjonuje na przykład w Kłodzku, gdzie spółka komunalna zarządza twierdzą, komunalnymi zasobami mieszkaniowymi, ośrodkiem rekreacji i sportu i dwoma basenami. Giżyckie Centrum Kultury zarządza miejskim domem kultury, kinem i Twierdzą Boyen. 


\section{Bibliografia}

Ashworth G., 2015. Planowanie dziedzictwa. Kraków. Międzynarodowe Centrum Kultury.

Kępczyńska-Walczak A., 2014. Zarządzanie dziedzictwem kulturowym w społeczeństwie opartym na wiedzy. Łódź. Wydawnictwo Politechniki Łódzkiej.

Podruczny G., T. Przerwa, 2010. Twierdza Srebrna Góra. Bellona.

Szmygin B., 2018. Światowe dziedzictwo kultury UNESCO - charakterystyka, metodologia, zarządzanie. Warszawa -Lublin. PKN ICOMOS, Politechnika Lubelska.

Tarnowska M., 2009. Organizacyjne uwarunkowania sprawności wdrażania systemu kompleksowego zarządzania jakością w przedsiębiorstwach przemysłowych. Poznań. Praca doktorska obroniona na Wydziale Zarządzania Uniwersytetu Ekonomicznego w Poznaniu pod kier. dr hab. Kazimierza Krzakiewicza, prof. UEP. 
